\title{
A Generic Micro-Cogeneration Model Adapted to Various Technologies for Building Energy Simulation Purpose
}

\author{
Romain Bonabe de Rougé ${ }^{1,2}$, Pierre Picard ${ }^{1,3}$, Pascal Stabat ${ }^{2}$, Dominique Marchio $^{2}$ \\ Efficacity, Champs-sur-Marne, France \\ Mines ParisTech - PSL Research University - CES, Paris, France \\ Engie Lab CRIGEN, Saint-Denis La Plaine, France
}

\begin{abstract}
A few numerical models of micro-cogeneration units have been implemented into Building Energy Simulation (BES) tools, especially within the framework of IEA ECBCS Annex 42 (Beausoleil-Morrison, 2008). However most of these models need a comprehensive set of parameters obtained from calibration with a large amount of experimental data. Moreover, models, parameters and experimental data may vary between different microcogeneration technologies. This paper presents a novel generic model of micro-cogeneration unit for BES purpose adapted to multiple technologies. The proposed correlation model includes descriptions of nominal and off-design stationary operation. It illustrates the construction of a set of parameters for this model based on data gathered from literature review, manufacturers datasheets and experimental works conducted by the authors. This dataset covers up-to-date market available units for five micro-cogeneration technologies over a wide range of power capacity.
\end{abstract}

\section{Introduction}

Building sector is the largest energy consumer in Europe with approximately $40 \%$ of the total energy use. European institutions are looking for solutions to lower energy demand and increase energy efficiency, especially for domestic and commercial buildings heat and electricity supply. Micro combined heat and power (micro-CHP) systems can lower primary energy consumption as they enable recovery of heat resulting from electricity generation by using it to satisfy the thermal building needs.

Upgrading boilers (100 million devices in Europe) with high efficiency technologies such as micro-CHP is one of many options to reduce primary energy consumption for both electricity and heat generation.

Various micro-CHP technologies are available on the market such as internal or external combustion engines, gas turbines or fuel cells. Integration of micro-CHP units to residential and commercial buildings is difficult due to their high investment cost and intermittent thermal and electrical loads. Difficulties are mainly related to sizing, design of hydraulic installation (including auxiliary burner and energy storages) and controls of the microCHP unit.

Compared to simple design methods, BES tools allow to better design Heating, Ventilation and Air-Conditioning
(HVAC) installations considering a more refined evaluation of system operating conditions (cycles, operating time, off-design performance...).

Recent works in the topic of micro-CHP modelling such as Leo, et al. (2017) and Ven Riet, et al. (2019) indicate that providing comprehensive information on the microCHP sizing methods, hydraulic and building integration is required to optimize seasonal performances of such systems.

A few numerical models of micro-cogeneration units have been implemented and tested into BES tools, especially within the framework of IEA ECBCS Annex 42 (Beausoleil-Morrison, 2008) and IEA ECBCS Annex 54 (Entchev \& Tzscheutschler, 2014). However most of these models such as those proposed by BeausoleilMorrison, et al. (2007) need a comprehensive set of parameters obtained from calibration with a large amount of experimental data. These data are not always publicly available or may be costly to gather as they require advanced experimental equipment.

Authors such as Dorer \& Weber (2008) attempted to use simplified or partial datasets to calibrate these models but usually with limited level of refinement compared to initial models.

Moreover, in the design of simulation models, many parameters and types of required experimental data may vary between different micro-cogeneration technologies. Therefore, most of literature studies present simulation results specific to one or few micro-CHP units. This also limits the ability of existing micro-CHP models to spread towards BES studies in engineering firms as a large set of parameters need to be gathered.

\section{Objectives}

This paper first presents a more generic (unifying all technologies) micro-cogeneration unit model adapted to annual BES and then a set of parameters for this model including five micro-cogeneration technologies, based on up-to-date market available units. For clarity, this paper is limited to the modelling of nominal and off-design stationary operation. Description of the modelling for transient operation and corresponding datasets will be presented in the future.

Compared to existing models and datasets, this work aims to accurately represent operating conditions of a "typical micro-cogeneration unit" for a given nominal power and 
a given technology to compute seasonal performance, without mandatory experimental data.

This work is thus a compilation of a large amount of heterogeneous performance data used to build systematic "standard" efficiency correlations using either existing literature correlations when suitable or new sets of equations if necessary, with adequate choice of influencing factors (or input).

\section{Model description}

\section{Technologies}

This paper focuses on five CHP technologies. The selection of these specific technologies is based on:

- market available units,

- existence of enough literature (manufacturers' datasheets, laboratory experimental data, field tests, etc.) containing performance information.

When it is possible, the scope of this study is covering 0 to $50 \mathrm{~kW}$ nominal electric power units. The studied micro-CHP systems are the following:

- Internal Combustion Engines (ICE)

- Fuel Cells (FC):

- Solid-Oxide Fuel Cells (SOFC)

- Proton-Exchange Membrane Fuel Cells (PEMFC)

- $\quad$ Stirling Engines (SE)

- $\quad$ Micro-Turbines (MT)

Micro-CHP Rankine and ORC units are not considered due to a lack of market available units in the studied power range since they are still in prototype phases. The numerical model could potentially be extended to other technologies, including Rankine, in the future.

\section{Nominal performances model}

First, nominal electric and thermal efficiencies $\eta^{\text {nominal }}$ need to be determined. The chosen approach is to define empirical laws describing evolution of nominal efficiencies according to nominal electric power $P_{e l}^{\text {nom }}$ for each technology. Pehnt et al. (2006) proposed logarithmic law (equation 1) for ICE efficiency, this law also turned to be relevant for other technologies and is therefore adopted in the model. Numerical results are presented in the section "Model parameters dataset".

$$
\eta^{\text {nominal }}=a \cdot \ln \left(P_{e l}^{\text {nom }}\right)+b
$$

\section{Selection of relevant influencing factors for off-design} performance computation

Relevant influencing factors for off-design (or nonnominal) performance computation were selected based on literature review of models and performance data for each technology. This literature review is separated and detailed for each influencing factor in "Model parameters dataset" section.

It reveals three main influencing factors on off-design stationary operation performances of micro-CHP units:

- Part load operation

- Inlet water temperature

- Inlet air temperature
Part load ratio (defined as the ratio of actual electric power and nominal electric power, equation 3) and inlet water temperature show significant effect on either electric or thermal efficiencies of all selected micro-CHP technologies.

Inlet air temperature has a usually very limited impact on all five technologies except for micro-turbines.

Additionally, a few studies as Bouvenot, et al. (2014) pointed limited effects of water flow rate on performances for a $1 \mathrm{~kW}_{\mathrm{el}}$ Stirling Engine. Also, Beausoleil-Morrison (2008) stated that this effect is experimentally difficult to separate from inlet water temperature influence. This influencing factor is thus discarded in the present model.

\section{Off-design stationary operation model}

\section{Literature review}

To describe off-design stationary performances, we adopt a combined approach between "efficiencies chain" as used by Bernier \& Bourret (1999) for variable frequency pumps in hydraulic systems and "normalized efficiencies" proposed by Bianchi, et al. (2014) for computation of "virtual operating cycles" and annual performances of micro-CHP units. Compared to Annex 42 approach, these models are well adapted to easily represent a range of micro-CHP of different nominal powers having similar behaviour regarding a given influencing factor.

\section{Proposed model}

The concept of the present model is to compute energy consumptions $P_{\text {fuel }}$, electrical $P_{e l}$ and thermal $\dot{Q}_{t h}$ production using thermal and electric efficiencies $\eta(t)$ computed at every instant. For both thermal and electric efficiencies, $\eta_{e l}(t)$ and $\eta_{t h}(t)$ are a product of "normalized" efficiencies describing relative decrease or increase of performance according to each influencing factor (inlet water temperature $T_{c w, i}$, part load ratio $P L R$ and inlet air temperature $\left.T_{\text {air }}\right)$ noted $\eta^{n, T_{c w, i}}(t)$, $\eta^{n, P L R}(t), \eta^{n, T_{a i r}}(t)$ and the nominal thermal or electric efficiency $\eta^{\text {nominal }}$.

$P L R$ is the control signal defining the level of power modulation at which the micro-CHP unit operates.

$$
\begin{gathered}
\left\{\begin{array}{c}
\eta_{e l}(t)=\eta_{e l}^{n, T_{c w, i}}(t) \cdot \eta_{e l}^{n, P L R}(t) \cdot \eta_{e l}^{n, T_{a i r}}(t) \cdot \eta_{e l}^{n o m i n a l} \\
\eta_{t h}(t)=\eta_{t h}^{n, T_{c w, i}}(t) \cdot \eta_{t h}^{n, P L R}(t) \cdot \eta_{t h}^{n, T_{a i r}}(t) \cdot \eta_{t h}^{\text {nominal }}
\end{array}\right. \\
P_{e l}=P L R \cdot P_{e l}^{\text {nominal }} \\
P_{f u e l}=\frac{P_{e l}}{\eta_{e l}} \\
\dot{Q}_{t h}=P_{f u e l} \cdot \eta_{t h}(t)
\end{gathered}
$$

To compute normalized thermal and electric efficiencies describing the influence of operating conditions, equation 6 is adopted for both inlet water temperature and PLR dependencies while equation 7 is used for inlet air temperature dependency.

$$
\begin{aligned}
& \eta^{n, X}=a \cdot X+\frac{b}{X}+c \\
& \eta^{n, T_{\text {air }}}=a \cdot T_{\text {air }}^{2}+b \cdot T_{\text {air }}+c
\end{aligned}
$$

Normalized off-design operation efficiency terms $\eta^{n, T_{c w, i}}(t), \eta^{n, P L R}(t), \eta^{n, T_{\text {air }}}(t)$ are assumed independent. It means, for example, that the relative variation of thermal 
efficiency vs PLR does not change according to inlet water temperature. The dataset proposed in the second part of this paper shows that this strong assumption is generally acceptable.

\section{Model parameters dataset}

This section illustrates the construction of a set of parameters for this model based on data gathered from literature review (detailed for each influencing factor), manufacturers datasheets and experimental works conducted by the authors (Bonabe de Rougé et al., 2016a; Bonabe de Rougé et al., 2016b). This dataset covers upto-date market available units for five micro-cogeneration technologies. For each micro-CHP technology, this part of the paper successively presents empirical correlations identified to set model parameters for:

- nominal efficiencies,

- off-design operation including:
○ part load sensitivity,
○ inlet water temperature sensitivity,
○ inlet air temperature sensitivity,

Normalized efficiencies used to model off-design operation are obtained by normalizing data for the following nominal conditions:

- inlet water temperature: $40{ }^{\circ} \mathrm{C}$

- part load ratio: $100 \%$

- inlet air temperature: $15^{\circ} \mathrm{C}$

\section{Nominal performance data}

Nominal efficiencies of Figure 1 to 5 are all collected from manufacturers datasheets. The model shows good correlations for nominal efficiencies of ICE, SE and MT micro-CHP units. For ICE, one distinguishes condensing and non-condensing units. While thermal efficiency is improved by condensing water vapour in flue gas (around $10 \%$ ), electric efficiency is not influenced as shown in Figure 1. For SE units (Figure 4), nominal efficiencies seem rather constant, but the power range is limited due to data availability. Only three MT units are available for capacity under $50 \mathrm{~kW}_{\mathrm{el}}$, thus performance data for units up to $200 \mathrm{~kW}_{\mathrm{el}}$ were used. FC units (Figure 2, Figure 3) show very heterogeneous nominal performances, this can be explained by the large variety and low maturity of technologies employed in such systems. Thus, no empirical correlation can be proposed.

\section{Internal Combustion Engines}

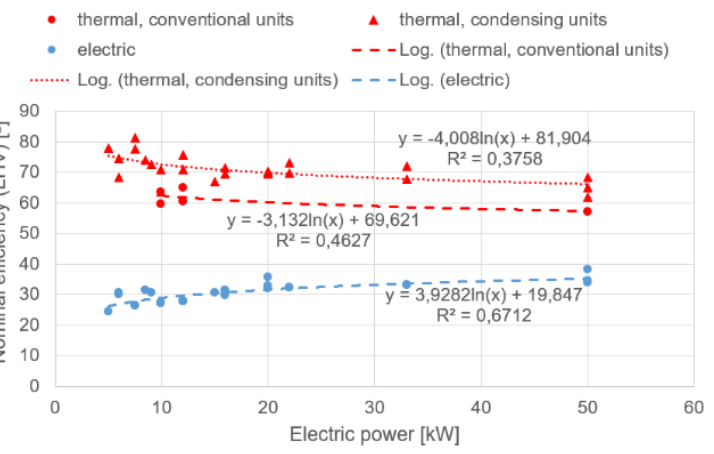

Figure 1: Nominal performances data of ICE micro-CHP with and without latent heat recovery
Fuel Cells

- $\quad$ Solid-Oxide Fuel Cells

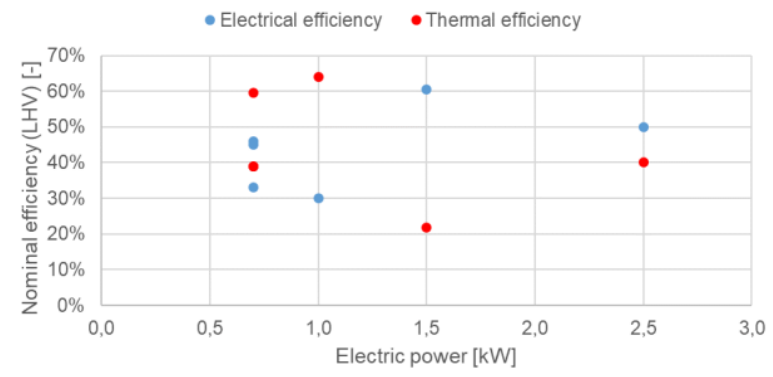

Figure 2: Nominal performances data of SOFC micro-CHP

- $\quad$ Proton-Exchange Membrane Fuel Cell

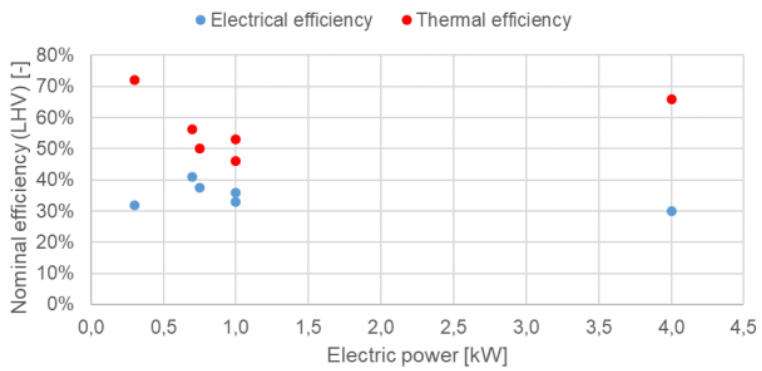

Figure 3: Nominal performances data of PEMFC micro-CHP

$\underline{\text { Stirling Engines }}$

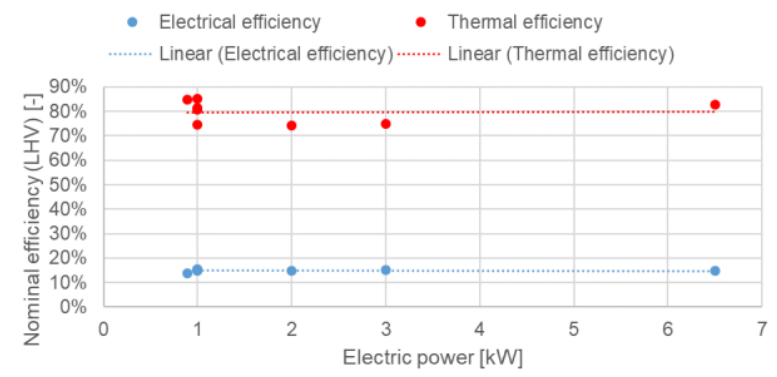

Figure 4: Nominal performances data of SE micro-CHP

Micro-Turbines

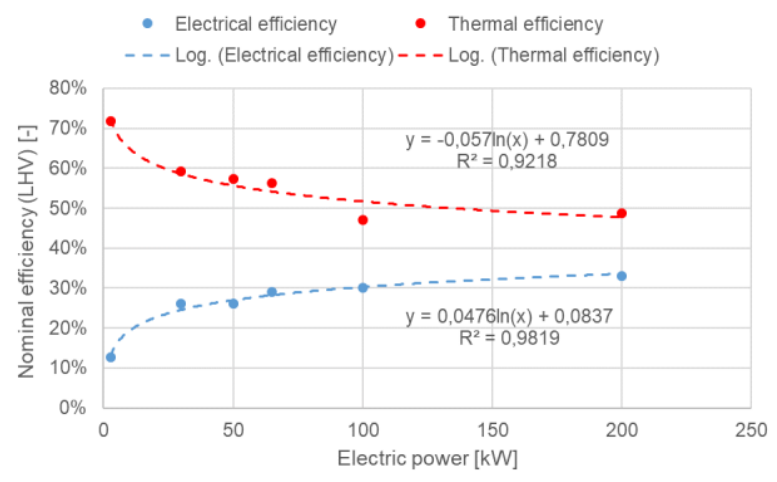

Figure 5: Nominal performances data of MT micro-CHP

\section{Part load sensitivity}

Micro-CHP units can usually modulate power output adjusting fuel input or rotation speed for example. In most 
of the cases, data show that part load operation implies a loss of efficiency except for thermal efficiency of ICE.

Data were collected from Arndt, et al. (2007), Bernd, et al. (2008), Bianchi, et al., (2014), Bush (2010), Capstone Turbine Corporation (2002), Dorer \& Weber (2008), Johnson, et al. (2012), Roselli, et al. (2010), Staffell (2015), Viessmann - ESS (2014), Wakui, et al. (2014), EC Power and Engie Lab CRIGEN.

For FC units, chosen empirical correlations are based on Staffel (2015). For ICE and MT, authors previous data and modelling work are used. For SE, inconsistent and scarce data cannot lead to a conclusion over a wide range of power.

When no other author or manufacturer is cited for data series in a figure, data are directly collected from previous experimental studies from present authors.

\section{Internal Combustion Engines}

Data measured at 40,50 and $60^{\circ} \mathrm{C}$ inlet water temperature (circular dots) for ICE units in Figure 6 demonstrate that part load performance degradation does not depend on water temperature and then validate the assumption proposed in "Model description" section for this particular case. Results for part load thermal efficiency are especially very satisfying.

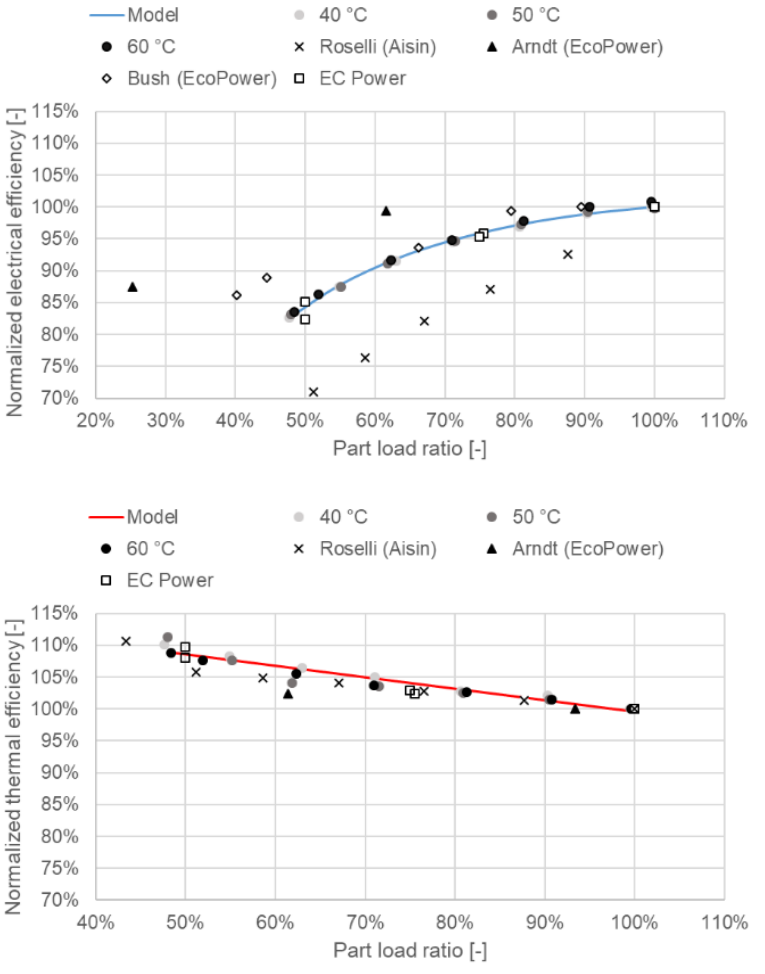

Figure 6: Normalized electric and thermal efficiencies according to part load operation of ICE micro-CHP

\section{Fuel Cells}

For SOFC (Figure 7), only two sets of part load performance data were available. These datasets do not always fit correlation proposed by Staffel (2015). The latter is based on experimental performance data from Japanese field-tests on multiple units. Thus, our generic model is based on Staffel correlations.
Staffel (2015) performance correlations for PEMFC (Figure 8) are consistent with other part load operation performance data and we chose to use Staffel correlations in the generic model for this technology.

- $\quad$ Solid-Oxide Fuel Cells
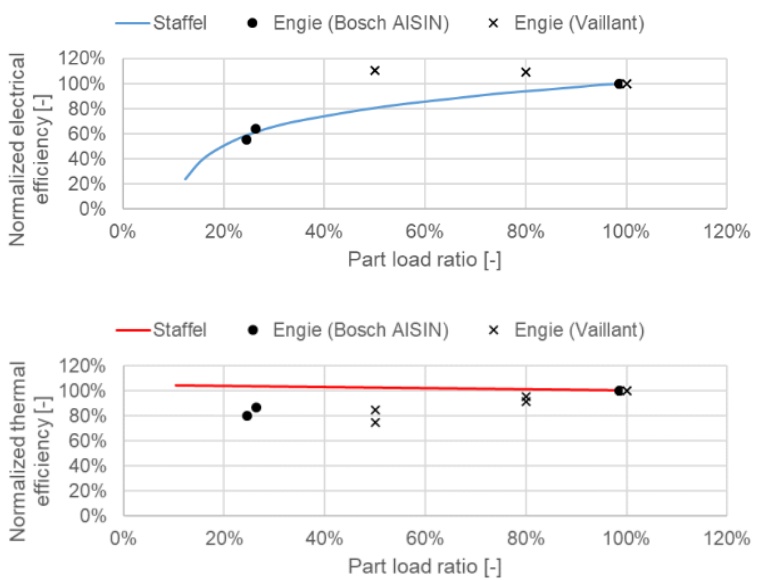

Figure 7: Normalized electric and thermal efficiencies according to part load operation of SOFC micro-CHP

- Proton-Exchange Membrane Fuel Cells
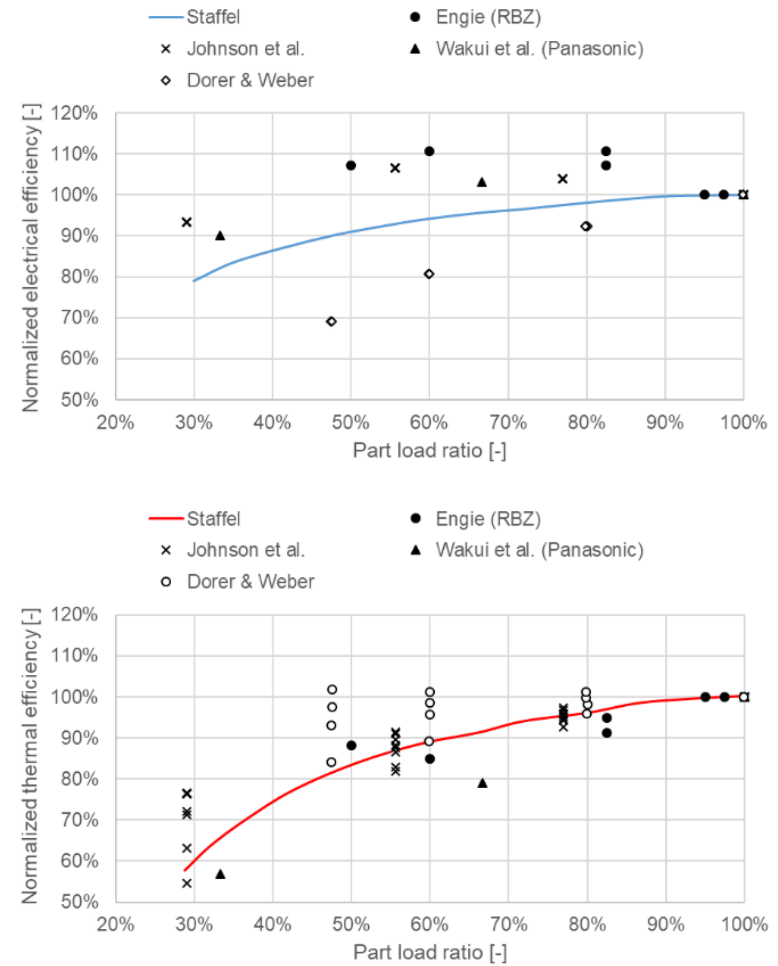

Figure 8: Normalized electric and thermal efficiencies according to part load operation of PEMFC micro-CHP

\section{Stirling Engines}

Figure 9 shows inconsistent and scarce data for SE and no evident conclusion. No correlation can be established. 

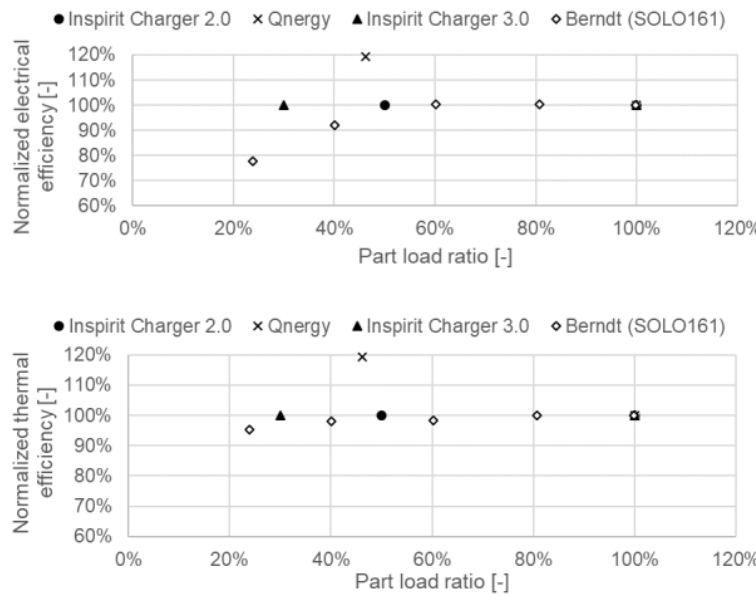

Figure 9: Normalized electric and thermal efficiency according to part load operation of SE micro-CHP

\section{Micro-Turbines}

Figure 10 and Figure 11 show good consistency between literature data but these slightly differ from our measurements. Gap cannot be explained thanks to available information. Furthermore, our measurements show that relative variation of efficiency according to $P L R$ does not seem independent of inlet air temperature (grey lines from $0{ }^{\circ} \mathrm{C}$ to $30{ }^{\circ} \mathrm{C}$ ). Also, thermal efficiency seems cross-dependent of inlet water temperature (Figure 10).

Both electric and thermal efficiencies relative variations seem more sensitive to inlet air temperature at very low part load operation, however MT units might not operate at very low part load as electric efficiency is critically decreased (up to $70 \%$ at $30 \%$ part load, Figure 11 ).

Therefore, adopted generic model is fitted for a unique inlet air temperature of $15^{\circ} \mathrm{C}$ (ISO conditions) and $30^{\circ} \mathrm{C}$ inlet water temperature.

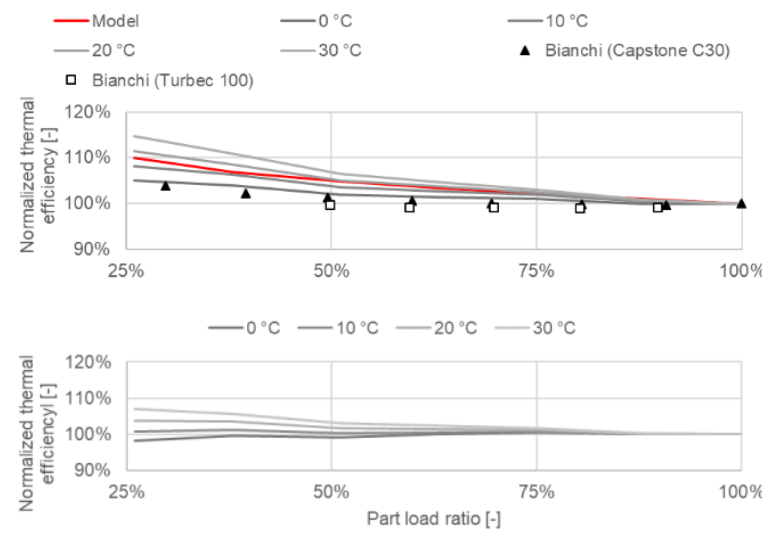

Figure 10: Normalized thermal efficiency according to part load operation of MT micro-CHP at $30{ }^{\circ} \mathrm{C}$ (top) and $60^{\circ} \mathrm{C}$ (bottom) inlet water temperature for multiple air temperatures

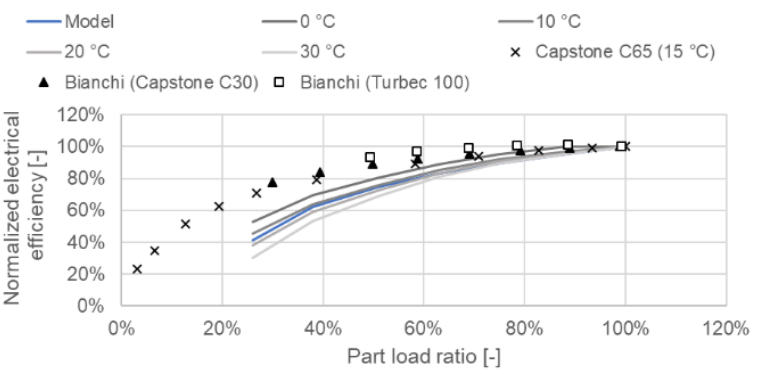

Figure 11: Normalized electric efficiency according to part load operation of MT micro-CHP for multiple air temperatures

\section{Inlet water temperature sensitivity}

Micro-CHP units can usually operate in a certain range of inlet temperature. According to the technology, inlet water may or may not be the cold source of the thermodynamic cycle. In most of the cases, data show no impact of inlet water temperature on electric production (except for SE), but increasing thermal efficiency at low inlet temperature.

Data were collected from Bouvenot, et al. (2014), Dorer \& Weber (2008), Johnson, et al. (2012), Matropasqua, et al. (2016), Viessmann - ESS (2014) and Engie Lab CRIGEN. For FC units, chosen correlations are based on Engie Lab CRIGEN data. For ICE and MT, authors previous data and modelling work are used. Finally, Bouvenot, et al. (2014) is the reference for SE (Figure 15 and Figure 16).

When no other author or manufacturer is cited for data series in a figure, data were directly collected from previous experimental studies from present authors.

Internal Combustion Engines

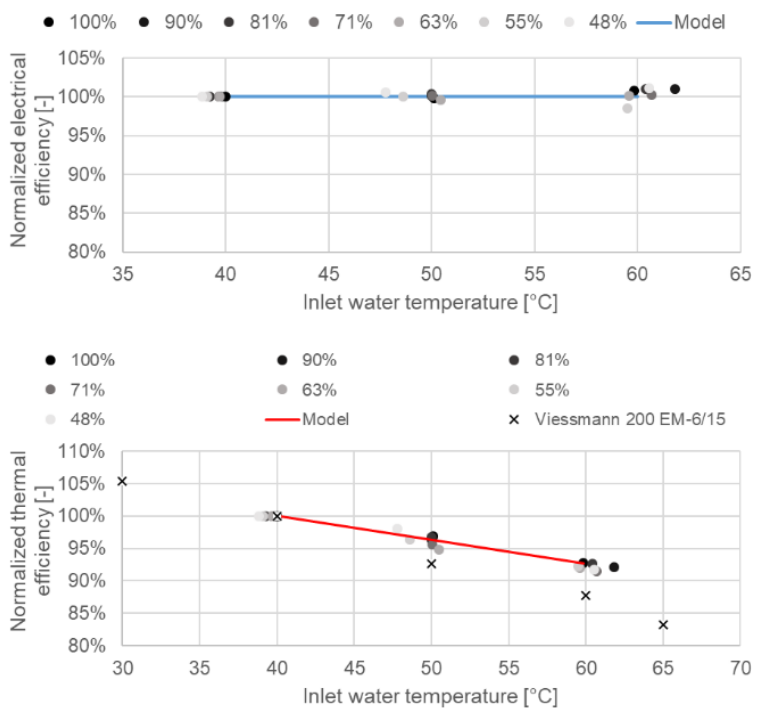

Figure 12: Normalized electric and thermal efficiencies according to inlet water temperature of ICE micro-CHP

Regarding ICE units, Figure 12 shows that relative thermal efficiency degradation according to inlet water temperature does not depend on part load operation. Correlations from authors experimental data cannot be compared to many other data and are therefore used for 
the generic model. Relative loss of thermal efficiency for a temperature rise of $1 \mathrm{~K}$ is about $0.4 \%$.

\section{$\underline{\text { Fuel Cells }}$}

Figure 13 and Figure 14 show very good overall consistency between all data for both SOFC and PEMFC. Correlations are fitted from Engie experimental data.

\section{- $\quad$ Solid-Oxide Fuel Cells}
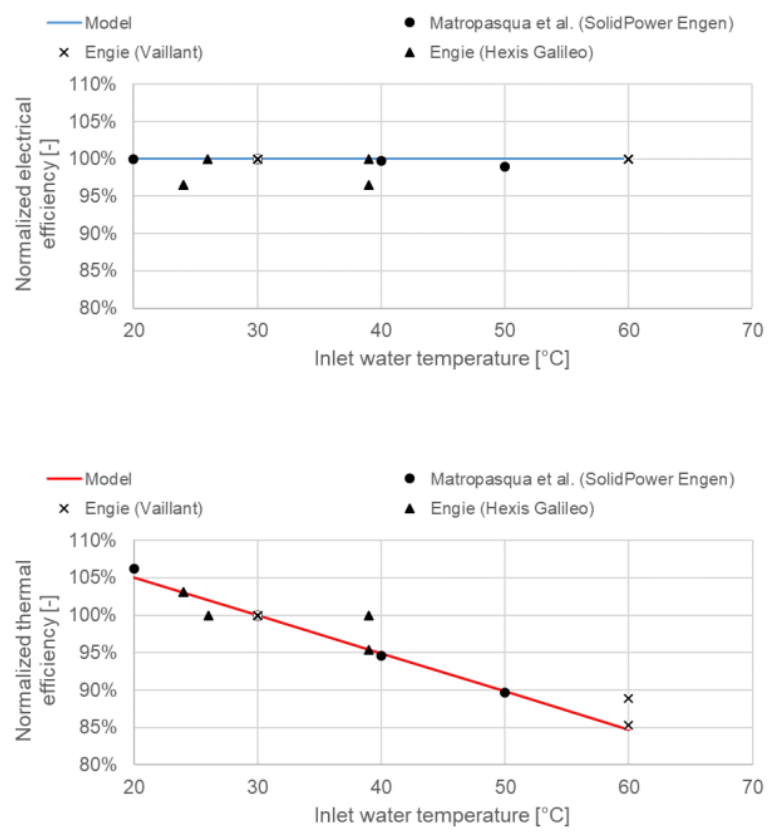

Figure 13: Normalized electric and thermal efficiencies according to inlet water temperature of SOFC micro-CHP

- $\quad$ Proton-Exchange Membrane Fuel Cells
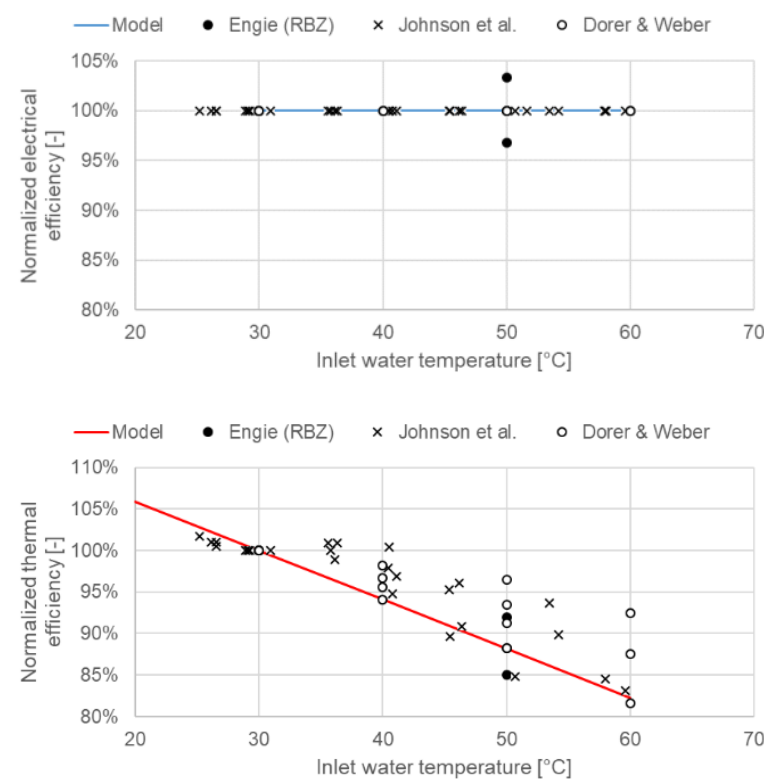

Figure 14: Normalized electric and thermal efficiencies according to inlet water temperature of PEMFC micro-CHP

\section{Stirling Engines}

Model correlations for SE units are fitted on Bouvenot et al. (2014) data as it is the more reliable set of performance data (peer-reviewed) for this technology. It seems consistent with other sources.

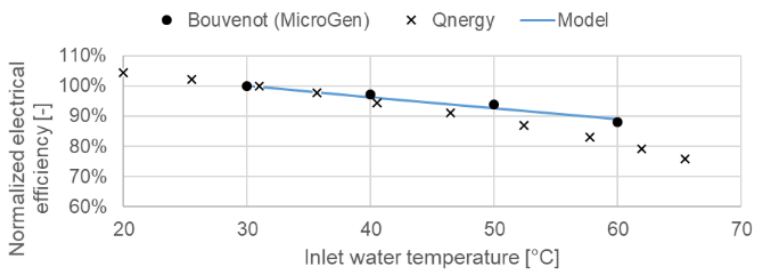

Figure 15: Normalized electric efficiency according to inlet water temperature of SE micro-CHP

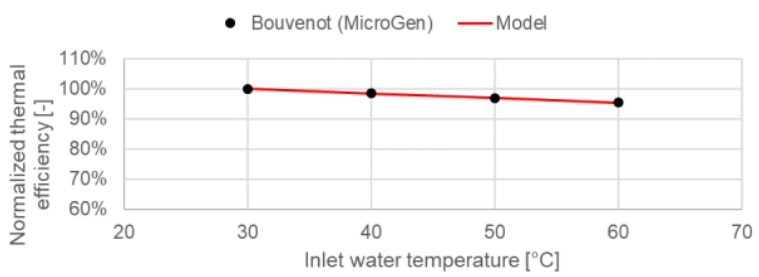

Figure 16: Normalized thermal efficiency according to inlet water temperature of SE micro-CHP

\section{Micro-Turbines}

Electric efficiency does not depend on inlet water temperature in gas turbines. Nevertheless, thermal efficiency (Figure 17) is dependent, like other technologies, due to thermal exchangers for heat recovery. Linear trends of experimental data collected at air temperature from $0{ }^{\circ} \mathrm{C}$ to $30^{\circ} \mathrm{C}$ (left) does not show a significant dependency on this variable. Thus, inlet water temperature correlation for MT thermal efficiency is fitted on authors experimental data (right).
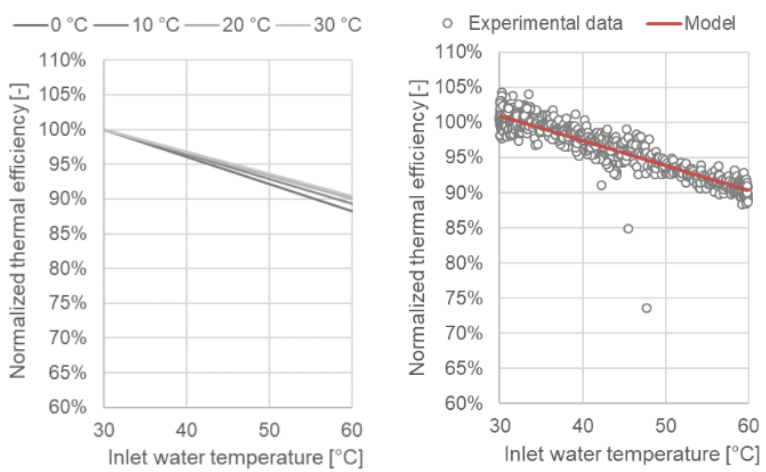

Figure 17: Normalized thermal efficiency according to inlet water temperature of MT micro-CHP (left) and illustration for different inlet air temperatures (right)

\section{Inlet air temperature sensitivity}

Only MT micro-CHP showed a significant impact of inlet air temperature on both electric and thermal efficiencies (Figure 18 and Figure 19). Manufacturers' data from Capstone and FlexEnergy are consistent with linear trends of authors experimental results at full load (100\% dotted line) presented on Figure 18. Yet, for electric efficiency, 
performance variation according to inlet air temperature is more sensitive at low part load ratio (60\% dotted line).

As MT units might operate more often at full load (better electrical performance), generic model is calibrated with full load performance data.

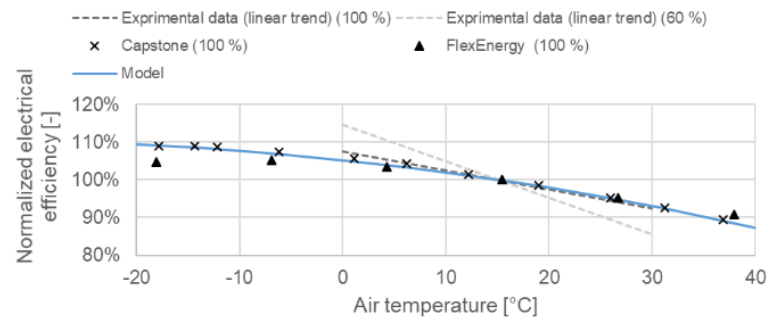

Figure 18: Normalized electric efficiency according to inlet air temperature of MT micro-CHP, lines represent trends of experimental data for various PLR

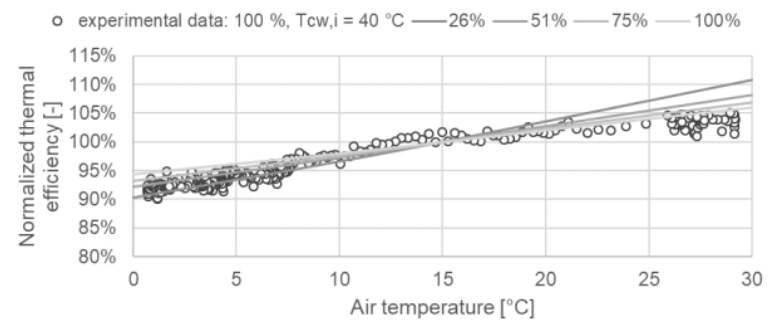

Figure 19: Normalized thermal efficiency according to inlet air temperature of MT micro-CHP, lines represent trends of experimental data for various PLR

\section{Conclusion}

This paper showed the development of a generic (or unified) numerical model of micro-CHP units for BES purpose and provides a dataset of parameters for five technologies over a wide range of power capacities.

Previous data allowed to identify:

- correlations for nominal performances except for FC units,

- correlations for off-design performances for three influencing factors except for part load operation of SOFC and SE units, due to a lack of consistent data.

A brief summary of variations of micro-CHP off-design performances according to the three selected influencing factors in stationary operation is presented in Table 1 . The sign "-" means "no influence" and "?" means "no correlation identified due to a lack of consistent data".

\begin{tabular}{|l|c|c|c|c|c|c|c|c|}
\hline \multirow{2}{*}{ Technology } & \multicolumn{2}{|c|}{ ICE } & \multicolumn{2}{c|}{ FC } & \multicolumn{2}{c|}{ SE } & \multicolumn{2}{c|}{ MT } \\
\cline { 2 - 9 } & Electric & Thermal & Electric & Thermal & Electric & Thermal & Electric & Thermal \\
\hline $\begin{array}{l}\text { Part load } \\
\text { ratio }\end{array}$ & $\nearrow$ & $\searrow$ & $\nearrow$ & $\nearrow / ?$ & $?$ & $?$ & $\nearrow$ & $\searrow$ \\
\hline $\begin{array}{l}\text { Inlet water } \\
\text { temperature }\end{array}$ & - & $\searrow$ & - & $\searrow$ & $\searrow$ & $\searrow$ & - & $\searrow$ \\
\hline $\begin{array}{l}\text { Inlet air } \\
\text { temperature }\end{array}$ & - & - & - & - & - & - & $\searrow$ & $\nearrow$ \\
\hline
\end{tabular}

Figure 20: Summary of variations of micro-CHP electric and thermal efficiencies according to three influencing factors

More experimental data should be collected (if possible) to gather unknown off-design stationary operation parameters. Also, the model could be extended to other technologies such as Rankine/ORC micro-CHP and other types of fuel cells.

Furthermore, this paper only focuses on stationary operation. Description of the transient operation modelling and corresponding collected data will be addressed in future work.

Finally, a comparison of this model with current detailed dynamic models of micro-CHP is also planned.

\section{Acknowledgement}

The authors would like to thank Efficacity for the funding of this work and Engie Lab CRIGEN for providing many experimental data and facilities.

\section{References}

Arndt, U., Beausoleil-Morrison, I. D., D'haeseleer, W., Dorer, V., Entchev, E., Ferguson, A., . . . Swinton, M. (2007). Experimental Investigation of Residential Cogeneration Devices and Calibration of Annex 42 Models. IEA.

Beausoleil-Morrison, I. (2008). An Experimental and Simulation-Based Investigation of the Performance of Small-Scale Fuel Cell and Combustion-Based Cogeneration Devices Serving Residential Buildings. Government of Canada.

Beausoleil-Morrison, I., Ferguson, A., Griffith, B., Kelly, N., Maréchal, F., \& Weber, A. (2007). Specifications for Modelling Fuel Cell and Combustion-Based Residential Cogeneration Devices within WholeBuilding Simulation Programs. IEA.

Bernd, T. (2008). Benchmark testing of Micro-CHP units. Applied Thermal Engineering, 2049-2054.

Bernier, M. A., \& Bourret, B. (1999). Pumping Energy and Variable Frequency Drives. ASHRAE Journal, $37-$ 40.

Bianchi, M., De Pascale, A., Melino, F., \& Peretto, A. (2014). Performance prediction of micro-CHP systems using simple virtual operating cycles. Applied thermal engineering, 771 - 779. 
Bonabe de Rouge, R., Partenay, V., Picard, P., Stabat, P., \& Marchio, D. (2016). Expérimentation d'une microcogénération à turbine à gaz sur un banc semi-virtuel et validation d'un modèle destiné à la simulation énergétique dynamique du bâtiment. IBPSA France Conférence, Paris, France.

Bonabe de Rouge, R., Tirtiaux, T., Picard, P., Stabat, P., \& Marchio, D. (2016). Experimental Analysis of a Gas Micro-Cogeneration Based on Internal Combustion Engine and Calibration of a Dynamic Model for Building Energy Simulation. CLIMA 2016 - proceedings of the 12th REHVA World Congress: vol. 3, Aalborg, Denmark.

Bouvenot, J.-B., Andlauer, B., Stabat, P., Marchio, D., \& Flament, B. (2014). Gas Stirling engine micro CHP boiler experimental data driven model for building energy simulation. Energy and Buildings, 117-131.

Bush, J. (2010). Modeling of CHP unit and evaluation of system performance in building applications. $M S c$ thesis.

Capstone Turbine Corporation. (2002). Product Specifications - Technical Specifications and Descriptions for a Single Capstone MicroTurbine. Manufacturer's data.

Dorer, V., \& Weber, A. (2008). Energy and CO2 emissions performance assessment of residential micro-cogeneration systems with dynamic wholebuilding simulation programs. Energy Conversion and Management, 50, 648-657.

Ellamla, H. R., Staffell, I., Bujlo, P., Pollet, B. G., \& Sivakumar, P. (2015). Current status of fuel cell based combined heat and power systems for residential sector. Journal of Power Sources, 312-328.

Entchev, E., \& Tzscheutschler, P. (2014). Integration of Microcogeneration and Related Technologies in Buildings - Final Report of Annex 54. München (Germany): Technische Universität München.

Johnson, G., Beausoleil-Morrison, I., Strathearn, B., Thorsteinson, E., \& Mackintosh, T. (2012). The calibration and validation of a model for simulating the thermal and electrical performance of a $1 \mathrm{kWAC}$ proton-exchange membrane fuel-cell microcogeneration device. Journal of Power Sources, 435446.

Leo, J., Bonabe de Rouge, R., Gavan, V., Stabat, P., \& Marchio, D. (2017). Assessment of an internal combustion engine micro-CHP for different office buildings performance scenarios. Building Simulation 2017. San Francisco (USA), 7-9 August 2017.

Matropasqua, L., Campanari, S., Valenti, G., Guariniello, A., Modena, S., \& Ghigliazza, F. (2016). Testing and preliminary modelling of a $2.5 \mathrm{~kW}$ micro-CHP SOFC unit. Proceedings of the ASME 2016 14th International Conference on Fuel Cell Science, Engineering and Technology, FUELCELL2016.
Pehnt, M., Cames, M., Fischer, C., Praetorius, B., Schneider, L., Schumacher, K., \& Voss, J.-P. (2006). Micro Cogeneration: Towards Decentralized Energy Systems. Berlin: Springer-Verlag Berlin Heidelberg.

Qnergy. (2014, June). Qnergy MCHP QB7500 Cogeneration System. Retrieved from http://www.tecsaving.com/wpcontent/uploads/2015/03/Presentazione-QEnergy.pdf

Roselli, C., Sasso, M., Sibilio, S., \& Tzscheutschler, P. (2010). Experimental analysis of microcogenerators based on different prime movers. Energy and Buildings, 796-804.

Staffell, I. (2015). Zero carbon infinite COP heat from fuel cell CHP. Applied Energy, 373-385.

U.S. Environmental Protection Agency CHP Partnership. (2015). Catalog of CHP technologies - Section 5. Technology Characterization - Microturbines.

Ven Riet, F., Janssen, E., Steenackers, G., \& Verhaert, I. (2019). Hydronic design of cogeneration in collective residential heating systems: state-of-the-art, comparison and improvements. Applied Thermal Engineering, 148, 1246-1257.

Viessmann - ESS. (2014). Vitobloc 200 type EM-6/15. Manufacturer's data.

Wakui, T., Wada, N., \& Ryohei, Y. (2014). Energysaving effect of a residential polymer electrolyte fuel cell cogeneration system combined with a plug-in hybrid electric vehicle. Energy Conversion and Management, 40-51. 